\title{
Expression of Peptidylglycine $\alpha$-Amidating Monooxygenase (EC 1.14.17.3) in the Rat Central Nervous System
}

\author{
Martin K.-H. Schafer,' Doris A. Stoffers, ${ }^{2}$ Betty A. Eipper, ${ }^{2}$ and Stanley J. Watson' \\ 'Mental Health Research Institute, University of Michigan, Ann Arbor, Michigan 48109-0720 and ${ }^{2}$ Department of \\ Neuroscience, The John Hopkins University School of Medicine, Baltimore, Maryland 21205
}

\begin{abstract}
An important step in the posttranslational modification of many bioactive neuropeptides, the carboxy-terminal amidation of glycine-extended peptides, is catalyzed by peptidylglycine $\alpha$-amidating monooxygenase (PAM; EC 1.14.17.3). The expression of the gene encoding this enzyme was examined in adult rat brain by in situ hybridization histochemistry and immunocytochemistry. PAM mRNA transcripts and PAM-like immunoreactivity were detected in all major brain areas with the exception of the cerebellum. Very high levels of PAM mRNAs were found in the hypothalamic magnocellular neurons, the hippocampal formation, and olfactory cortex. These areas also showed strong PAM-like immunoreactivity. Regions known to contain high levels of amidated neuropeptides also expressed high levels of PAM mRNA. The observed heterogeneous PAM mRNA levels may reflect differences in the peptidergic activity of different neuronal systems. Interestingly, all pyramidal neurons of the hippocampus expressed very high levels of PAM mRNA, although no identified amidated peptide matches this distribution completely. Furthermore, PAM was not expressed exclusively in neuronal tissue but was also present in nonneuronal tissue. PAM transcripts could be localized in certain ventricular ependymal cells, with the highest expression in the lateral ventricle. Localization of PAM to non-neuronal cells and neurons not known to produce $\alpha$-amidated peptides suggests that these cells may be producing as yet unidentified amidated neuropeptides.
\end{abstract}

Peptidergic neurons are involved in the regulation of a variety of CNS functions. Until recently, biochemical examinations of the physiological regulation of peptidergic neurons have been limited to analysis of the biosynthesis of neuropeptides. Bioactive neuropeptides derive from larger precursor molecules, which undergo a variety of cotranslational and posttranslational modifications during their biosynthesis. Recent advances in the molecular characterization of two of these posttranslational processing enzymes, peptidylglycine $\alpha$-amidating monooxygenase (PAM; EC 1.14.17.3) and carboxypeptidase H (CPH or CPE;

Received Apr. 12, 1991; revised Aug. 20, 1991; accepted Aug. 26, 1991

This work was supported by grants from the National Institute of Mental Health (MH 4222251), the National Institute of Drug Abuse (DA02265 and DA00266 and NIDDK DK07245). We thank Sharon Burke for the excellent technical as sistance with the immunocytochemical studies. We are also indebted to Richard Mains, James Herman, and Alfred Mansour for invaluable discussions and critical reading of the manuscript.

Correspondence should be addressed to Stanley J. Watson, M.D., Ph.D., Mental Health Research Institute, University of Michigan, 205 Washtenaw Place, Ann Arbor, MI 48109-0720.

Copyright (C) 1992 Society for Neuroscience $0270-6474 / 92 / 120222-13 \$ 05.00 / 0$
EC 3.4.17.10) (Eipper et al., 1988; Fricker, 1988), have generated the necessary molecular tools to begin studying the regulation of peptidergic neurons by studying processing enzymes. For many neuropeptides, a carboxyl-terminal $\alpha$-amide moiety is essential for biological activity (Eipper and Mains, 1988). For example, corticotropin releasing hormone $(\mathrm{CRH})$ is about a thousandfold more potent in its amidated form (Vale et al., 1981).

Peptide $\alpha$-amidation involves the sequential action of two enzymes contained within the PAM protein (Fig. 1) (Young and Tamburini, 1989; Katapodis et al., 1990; Perkins et al., 1990; Tajima ct al., 1990; Takahashi ct al., 1990). Peptidylglycine $\alpha$-hydroxylating monooxygenase (PHM), situated in the $\mathrm{NH}_{2}-$ terminal third of the PAM precursor, catalyzes the conversion of carboxyl-terminal glycine extended peptides into peptidyl- $\alpha$ hydroxylglycine intermediates in a copper-, ascorbate-, and molecular oxygen-dependent reaction. Peptidyl- $\alpha$-hydroxylglycine $\alpha$-amidating lyase (PAL), situated in the middle of the PAM precursor, is required to calalyze the $\alpha$-amidation of this intermediate at physiological pH (Perkins et al., 1990). cDNAs encoding PAM have been cloned from bovine intermediate pituitary, frog skin, rat heart, and human thyroid carcinoma (Eipper et al., 1987; Mizuno et al., 1987; Ohsuye et al., 1988; Stoffers et al., 1989; Glauder et al., 1990). Several forms of PAM mRNA have been described (Fig. 1); all are thought to derive from a single primary RNA transcript via alternative splicing (Stoffers et al., 1989, 1991; Kato et al., 1990). Changes in levels of PAM expression may have important implications for the biosynthesis of neuropeptides and peptidergic function. For example, glucocorticoids and second messengers such as cAMP alter the expression of propeptides and PAM in AtT-20 cells and primary heart cells in a tissue-specific fashion (Thiele et al., 1989). Overand underexpression of PAM in AtT-20 cells alter the ability of the cells to produce $\alpha$-amidated product peptides, indicating that PAM can be a rate-limiting enzyme in peptide biosynthesis (Mains et al., 1991).

Given the wide variety and high concentration of amidated neuropeptides in the CNS, it is not surprising that $\alpha$-amidation activity has been found at fairly high levels in the CNS (Eipper et al., 1985; Sakata et al., 1986; Meng and Tsou, 1988). The level of PAM activity was particularly high in the hypothalamus, where its localization to secretory granules was demonstrated. Approximately half of the PAM activity in various regions of the rat CNS was soluble. Northern blot analysis and reverse transcription coupled with PCR demonstrated the presence of two major forms of PAM mRNA (rPAM-1 and rPAM-2) in several rat brain regions (Braas et al., 1989; Stoffers et al., 1991). 
The goal of this study was to examine the general anatomical distribution pattern of PAM gene expression in the CNS using in situ hybridization and immunohistochemistry as the histochemical tools. We generated high specific activity ${ }^{35} \mathrm{~S}$-labeled riboprobes complementary to a region common to the major PAM mRNA forms isolated from rat heart to examine the general expression pattern of the PAM gene. Region-specific alternative splicing patterns of the PAM gene were not examined. The immunocytochemical studies focused on selected areas with medium to high levels of PAM mRNA to examine the presence of PAM-like products in these tissues.

\section{Materials and Methods}

Tissue preparation. For in situ hybridization, male Sprague-Dawley rats (200-250 gm body weight) were killed by decapitation between 9:00 and 10:00 A.M. The brains were rapidly removed and frozen in isopentane cooled to $-40^{\circ} \mathrm{C}$ on dry ice. For immunohistochemistry, rats were perfused with phosphate-buffered $4 \%$ formaldehyde following barbiturate anesthesia; brains were blocked and postfixed for $2 \mathrm{hr}$. After incubation in a $20 \%$ sucrose solution overnight, the tissue was frozen in liquid nitrogen. Sections (10-20 $\mu \mathrm{m}$ thick) were cut on a cryostat (Hacker Instruments). To block axonal transport, some animals were injected with colchicine $(0.75 \mathrm{mg} / \mathrm{kg}$ body weight $)$ in the lateral ventriclc $48 \mathrm{hr}$ prior to death.

Probe synthesis. Two Bluescript plasmids (Strategene) containing rat PAM cDNA fragments were utilized to generate cRNA probes. pBS.del 7-2 [nucleotides (nt) 117-1197] was one of a set of nested deletion mutants; pBS.CVI contained the 1.8 kilobase $(\mathrm{kb})$ EcoRI-BstEII fragment of the ZAP 6 rat PAM-1 cDNA (nt 117-1903). Probe 1 (nt 164 1197) was generated from linearized pBS.del 7-2 (restriction enzyme MluI) using T7 RNA polymerase (Promega) and ${ }^{35}$ S-UTP as radioactive label. This cRNA probe had a specific activity of $2.95 \times 10^{5} \mathrm{Ci} / \mathrm{mmol}$. Probe 2 (nt 619-1903) was produced from linearized pBS.CVI (restriction enzyme NdeI) using T7 RNA polymerase as well and yielded a specific activity of $3.75 \times 10^{5} \mathrm{Ci} / \mathrm{mmol}$. The generated riboprobes did not differentiate between the different PAM mRNA forms as illustrated in Figure 1. Sense-strand probes used as controls were generated using T3 RNA polymerase.

In situ hybridization histochemistry. Frozen sections were fixed in $4 \%$ formaldehyde for $60 \mathrm{~min}$ at room temperature (RT) and then washed in $0.05 \mathrm{M}$ PBS, $\mathrm{pH} 7.4$, for $10 \mathrm{~min}$. Deproteination was carried out with proteinase $\mathrm{K}(1 \mu \mathrm{g} / \mathrm{ml})$ for $10 \mathrm{~min}$ at $37^{\circ} \mathrm{C}$. Slides were transferred to $0.1 \mathrm{~m}$ triethanolamine, $\mathrm{pH} 8.0$, and incubated in the same solution containing acetic anhydride $(0.25 \%, \mathrm{v} / \mathrm{v})$ for $10 \mathrm{~min}$ at RT. Sections were then rinsed in $2 \times$ saline-sodium citrate (SSC) and dehydrated in ethanol (50-100\%). Radioactive cRNA probes were diluted in hybridization buffer [ $75 \%$ formamide, $10 \%$ dextran sulfate, $3 \times$ SSC, $50 \mathrm{~mm}$ $\mathrm{NaPO}_{4}, \mathrm{pH} 7.4,1 \times$ Denhardt's $(0.02 \%$ of each, Ficoll 400 , polyvinylpyrrolidone, BSA), $0.1 \mathrm{mg} / \mathrm{ml}$ yeast RNA] to a final concentration of $34 \times 10^{4} \mathrm{dpm} / \mu \mathrm{l}$. Dithiothreitol was added to a final concentration of $10 \mathrm{~mm}$. Hybridization mix (30-50 $\mu 1$ per slide) was applied, and sections were coverslipped and sealed with rubber cement. The tissue was incubated in the hybridization oven at $55^{\circ} \mathrm{C}$ for $16 \mathrm{hr}$. The next day, coverslips were removed in $2 \times \mathrm{SSC}$. Sections were treated with RNase A $(200 \mu \mathrm{g} / \mathrm{ml})$ at $37^{\circ} \mathrm{C}$ for $60 \mathrm{~min}$ to remove single-stranded RNA molecules. Successive washes followed at RT in $2,1,0.5$, and $0.2 \times$ SSC for $10 \mathrm{~min}$ each and in $0.2 \times \mathrm{SSC}$ at $60^{\circ} \mathrm{C}$ for $1 \mathrm{hr}$. The tissue was then dehydrated and exposed to Kodak XAR x-ray film for $1-4 \mathrm{~d}$. For microscopic analysis, sections were dipped in Kodak NTB2 nuclear emulsion and developed following exposure times of 1-8 weeks. As negative controls, tissues were either treated with RNase A $\left(200 \mu \mathrm{g} / \mathrm{ml}\right.$ at $37^{\circ} \mathrm{C}$ for $60 \mathrm{~min}$ ) prior to hybridization or probed with the sense-strand probes.

Antibodies. Polyclonal antisera were produced in rabbits to various synthetic peptide fragments of the bovine PAM precursor protein (see Fig. 1). Antibody (Ab) 59 was raised against the PHM domain (bPAM 288-310); Ab 69, to the PAL domain (bPAM 561-579); Ab 74, to the cytoplasmic domain (bPAM 945-961), and $\mathrm{Ab} 77$, against the $\mathbf{N H}_{2}$ terminal part of the bovine precursor (bPAM 143-161). These antibodies are able to recognize the corresponding rat sequences due to high sequence homology across species. Prior to use, antibodies were affinity purified as described elsewhere (Ouafik et al., 1989). All antibodies used
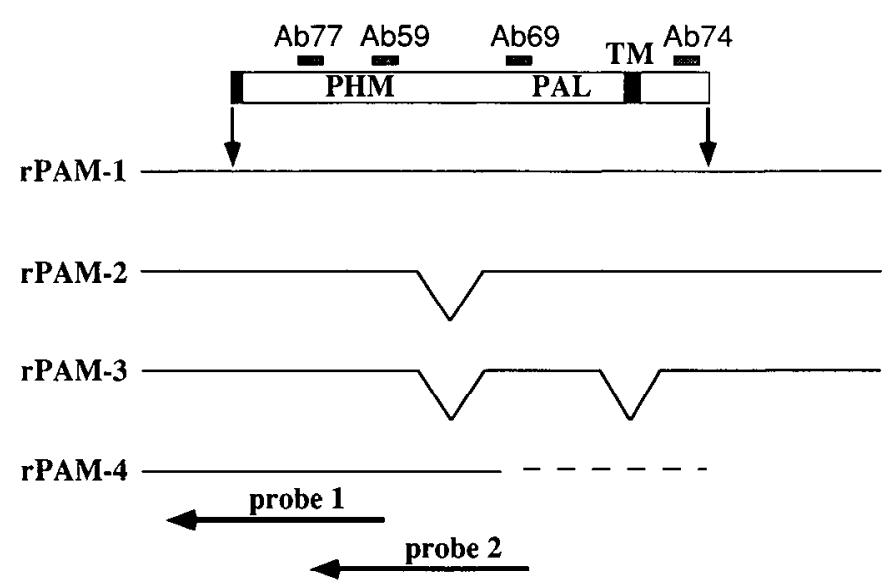

Figure 1. Schematic illustration of PAM mRNAs, protein precursor, and corresponding probes. The PAM precursor protein (top) consists of a signal peptide (solid rectangle at left), two catalytic domains (peptidylglycine $\alpha$-hydroxylating monooxygenase $(P H M)$ and peptidyl- $\alpha$ hydroxyglycine $\alpha$-amidating lyase $(P A L)$ ], a transmembrane domain $(T M)$, and a cytoplasmic domain. A single gene encodes PAM; alternative splicing generates a tissue-specific pattern of expression. PAM-1 and PAM-2 are the major mRNA forms in the CNS. Additional variants lacking parts of the nt 258 segment missing in $r P A M-3$ have been identified (Kato et al., 1990; Stoffers et al., 1991). The riboprobes used in this study (arrows) hybridize to all known PAM mRNAs. The locations of synthetic peptides used to generate the rabbit polyclonal antisera used in this study are indicated on the diagram of the PAM precursor. All antibodies gave positive immunostaining. The best results were obtained using $\mathrm{Ab} 74$, which recognizes the $\mathrm{COOH}$-terminal portion of the PAM precursor.

in this study produced a very similar, if not identical, immunostaining pattern.

Although antibody cross-reactivities and specificities were examined previously (Ouafik et al., 1989), working dilutions of antibodies used in this study were preabsorbed in solution with $10 \mu \mathrm{M}$ concentrations of the appropriate antigen for $16 \mathrm{hr}$ at $4^{\circ} \mathrm{C}$ prior to use. To examine potential cross-reactivities, all antibodies were preabsorbed with $50 \mu \mathrm{M}$ concentrations of the following peptides: Arg-vasopressin, oxytocin, CRH, dynorphin (1-17), (Leu)enkephalin, cholecystokinin (CCK), adrenocorticotropic hormone, $\alpha$-melanocyte-stimulating hormone. None of the antisera showed cross-reactivity to any of these peptides.

Immunocytochemistry. Sections were thawed at room temperature and preabsorbed with normal goat serum (1:30) for $5 \mathrm{~min}$. Primary affinity-purified antibody (dilution, 1:250) was applied, and sections were incubated for $16 \mathrm{hr}$ at $4^{\circ} \mathrm{C}$. The next day, sections were washed three times in $0.05 \mathrm{M}$ PBS, $\mathrm{pH}$ 7.4. Biotinylated goat anti-rabbit serum (Vector Laboratories) was applied $(1: 200)$ for $30 \mathrm{~min}$ at RT. Three washes in PBS followed. Tissue was then incubated with avidin-biotinperoxidase complex $(1: 250)$ for $30 \mathrm{~min}$. Following three washes in PBS, sections were incubated for color reactions in a solution containing 0.125 $\mathrm{mg} / \mathrm{ml}$ diaminobenzidine and $0.003 \% \mathrm{H}_{2} \mathrm{O}_{2}$ for $10 \mathrm{~min}$. Slides were washed in $\mathrm{H}_{2} \mathrm{O}$, dehydrated through ethanols and xylenes, and then coverslipped in Permount for microscopic examination.

\section{Results}

Using in situ hybridization histochemistry to analyze the cellular expression pattern of the PAM gene at the mRNA level, we observed over many brain areas positive autoradiographic signals. To exclude false-positive hybrididization results, probe specificity was confirmed by several means. When serial brain sections were probed with either of the two PAM cRNA probes (Fig. 1), identical labeling patterns were evident, supporting the specificity of the hybridization signals. Pretreatment of brain sections with RNase $A$ abolished all specific hybridization. In addition, hybridization with sense-strand coding probes did not 


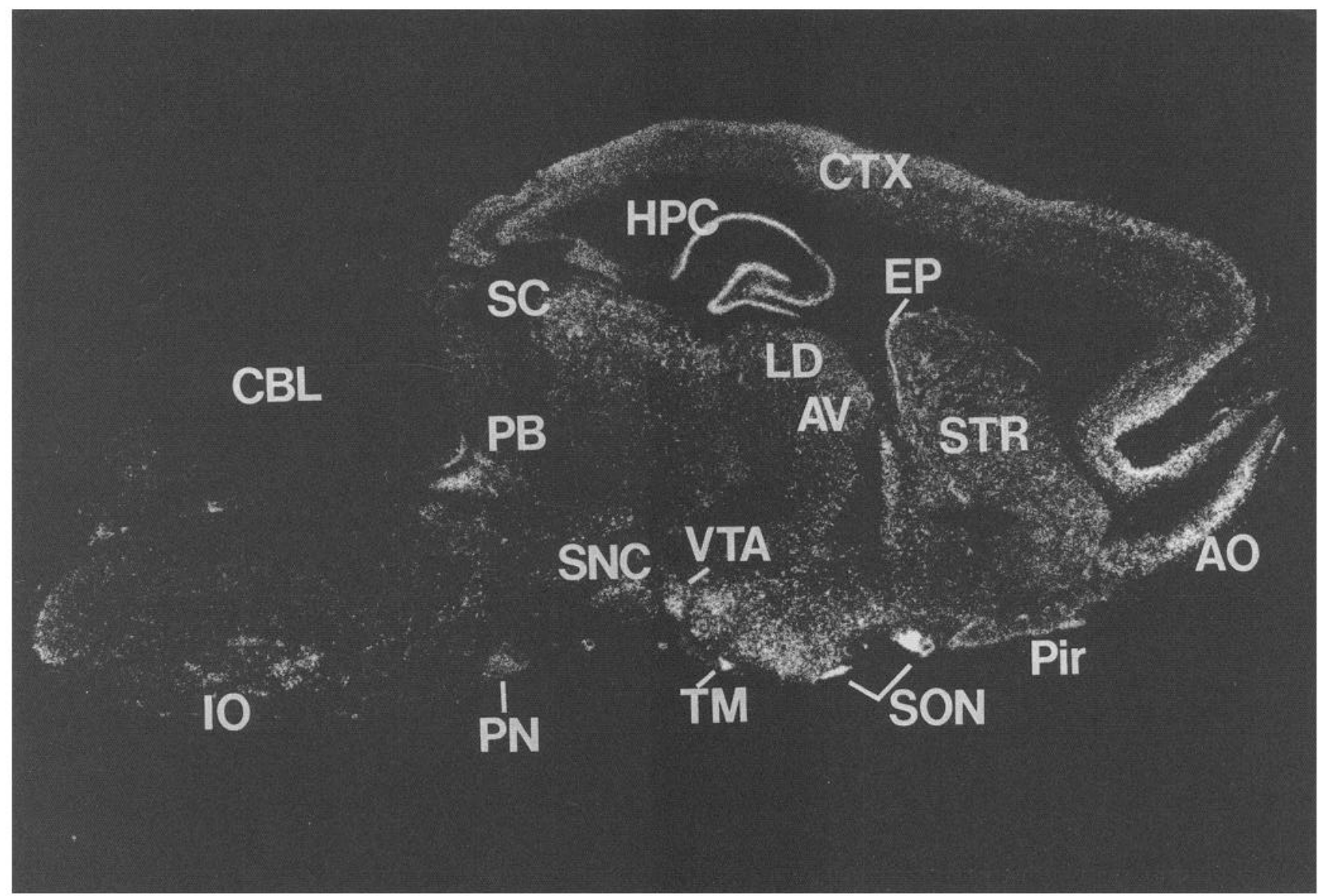

Figure 2. Dark-field autoradiogram of a sagittal rat brain section showing the general distribution of PAM mRNA in adult rat brain. The frozen section is approximately $1.4 \mathrm{~mm}$ sagittal to the midline. Section was hybridized with a ${ }^{35} \mathrm{~S}$-labeled cRNA probe (probe 1 ). X rays were developed following a $48 \mathrm{hr}$ exposure. Note the positive hybridization signals with different intensities in almost all brain regions except the cerebellum. $A O$, anterior olfactory nucleus; $A V$, anteroventral thalamic nucleus; $C B L$, cerebellum; $C T X$, cortex; $E P$, ependyma; $H P C$, hippocampal formation; $I O$, inferior olive; $L D$, laterodorsal thalamic nucleus; $P B$, parabrachial nucleus; Pir, piriform cortex; $P N$, pontine nuclei; $S C$, superior colliculus; $S N C$, substantia nigra pars compacta; $S O N$, supraoptic nucleus; $S T R$, striatum; $T M$, tuberomamillary nucleus; $V T A$, ventral tegmental area.

show any specific signals, further demonstrating the specificity of the hybridization.

PAM mRNA showed a broad distribution throughout the rat brain as illustrated in Figure 2. The highest levels of PAM mRNA were observed in the hypothalamus in the magnocellular nuclei, the hippocampal formation, the olfactory cortex, and certain brainstem nuclei. Other brain regions examined for PAM mRNA expression are listed in Table 1. Interestingly, no specific labeling was observed over the entire cerebellum (Fig. 2), even following longer exposure times of up to 2 months. We therefore concluded that, if the PAM gene is expressed in this brain region, it is present at levels that are below detection by our in situ procedure. Selected regions were examined in more detail.

Olfactory system. The anterior olfactory nucleus and the piriform cortex were among the brain areas with the highest expression of PAM mRNA. In the olfactory bulb, a medium dense to dense labeling was observed in distinct layers (Fig. $3 A$ ). Fairly high PAM mRNA levels were exhibited in the mitral cells (Fig. $3 B$ ), the main source of olfactory bulb projection fibers, and cells in the glomerular layer (Fig. $3 C$ ). Densely labeled neurons, most likely identified as middle tufted cells, were observed along the medial border of the external plexiform layer. Medium dense labeling occurred over tufted cells. A faint positive hybridization signal was present over the intragranular cell layer.

Telencephalon. Within the telencephalon, high levels of PAM transcripts were observed throughout the cortical areas, particularly the anterior cingulate cortex (Fig. 4) and the parietal cortex. In the neocortex, PAM mRNA seemed to be distributed in two major bands, one representing layers two and three, the other layers five and six (Fig. 2). A similar distribution was observed for CCK mRNA by others previously (Siegel and Young, 1985; Savasta et al., 1988; Ingram et al., 1989). Brightfield examination revealed both cortical pyramidal neurons and nonpyramidal neurons as the PAM mRNA-producing cells. In colchicine-pretreated animals, the pyramidal cell layers again showed strong PAM-like immunoreactivity (Fig. 4B).

The hippocampal formation was one of the brain regions expressing the highest levels of PAM mRNA (Fig. 5). Following only an overnight exposure, the entire hippocampal formation was visible on x-ray film. All four regions of Ammon's horn exhibited strong hybridization signal. The densest labeling was observed over CA1, CA3, and CA4, with the region of CA2 neighboring $\mathrm{CA} 3$ being distinctly less intense (Fig. $5 A$ ). In addition, the dentate gyrus showed strong labeling, although less 
Table 1. Distribution of PAM mRNA in the rat brain

PAM mRNA

Brain area

I. Telencephalon

Cingulate cortex

Frontal parietal cortex

Piriform cortex

Entorhinal cortex

Temporal cortex

Striate cortex

Endopiriform n.

Olfactory tubercle

Olfactory cortex

Amygdala

Medial nucleus

Central nucleus

Cortical nucleus

Basolateral nucleus

Hippocampal formation
CAl
$\mathrm{CA} 2$
CA3
CA4

Dentate gyrus

Molecular layer

Granular layer

Subiculum

Nucleus accumbens

Caudate putamen

Globus pallidus

Septum

Lateral

Medial

Bed nucleus stria terminalis

Medial preoptic area

II. Diencephalon

Hypothalamus

Anterior hypothalamic area

Supraoptic nucleus

Periventricular nucleus

Paraventricular nucleus

Magnocellular

Medial parvocellular

Lateral parvocellular

Dorsal parvocellular

Arcuate nucleus

Median eminence

Suprachiasmatic nucleus

Ventromedial nucleus

Dorsomedial nucleus

Lateral hypothalamic area

Medial mammillary nucleus

Tuberomamillary nucleus

Thalamus

Periventricular nucleus

Anteroventral nucleus

Anteromedial nucleus

Anterodorsal nucleus abundance

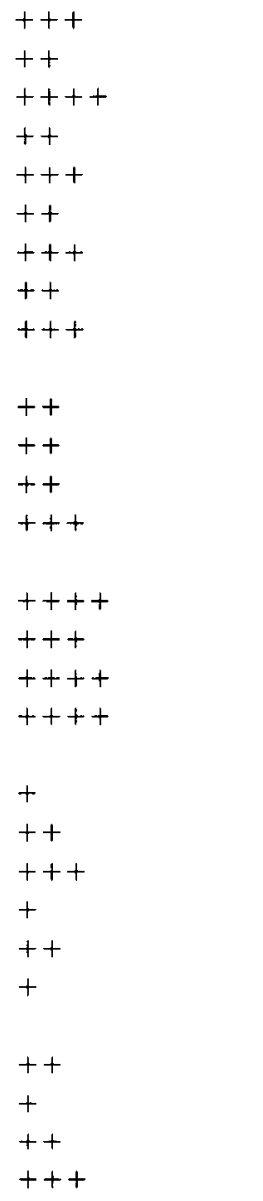

$++$

$+++$

$++$

$+++$

$+++$

$+++$

$++$

$+++$

$++$

$+$

$++$

$++$

$++$

$++$

$++$

$+++$

$++$

$++$

$++$

$++$
Table 1. Continued

Brain area

PAM mRNA

$\frac{\text { Brain area }}{\text { Mediodorsal nucleus }}$

Reticular nucleus

Ventral posteriolateral nucleus

Ventral posteriomedial nucleus

Suprageniculate nucleus

Peripeduncular nucleus

Posterior group

Habenula

Medial

Lateral

Subthalamic nucleus

abundance

III. Mesencephalon

Interpeduncular nucleus

Substantia nigra

Pars compacta

Pars reticulata

Ventral tcgmental arca

Periaquaeductal gray

Superior colliculus

$++$

$+$

$++$

$++$

$+++$

$++$

$++$

$++$

$+$

$++$

$++$

$+++$

0

$+++$

$++$

$+++$

$++$

$++$

Medium raphe nucleus

Dorsal raphe nucleus

Dorsal tegmental nucleus

$++$

$++$

IV. Cerebellum

0

V. Pons and medulla

Pontine nucleus

Parabrachial nucleus

Nucleus raphe magnus

Nucleus gigantocellularis

Nuclcus facialis

Nucleus of the solitary tract

Lateral reticular nucleus

Spinal trigeminal nucleus

Inferior olive

Raphe pallidus nucleus

Raphe obscurus nucleus

Medial vestibular nucleus

Lateral vestibular nucleus

Cochlear nucleus

Subpeduncular nucleus

Dorsal motor nucleus of vagus

Anterior horn of spinal cord

Dorsal horn of spinal cord

$+++$

$+++$

$+$

$++$

$+1$

$+++$

$++$

$++$

$+++$

$++$

$++$

$+++$

$+++$

$+++$

$+++$

$+++$

$+$

$++$

VI. Non-neuronal tissue

Ependyma

Anterior horn of lateral ventricle

$+++$

Cerebral arteries

Adventitia

$++$

Intima

$+$

Glia

NA

This table presents a subjective evaluation of PAM mRNA abundance in different brain areas from three different in situ hybridization experiments. Density: ++++ , very dense; +++ , dense; ++ moderate; + , light; 0 , undetectable; $N A$, not available. 

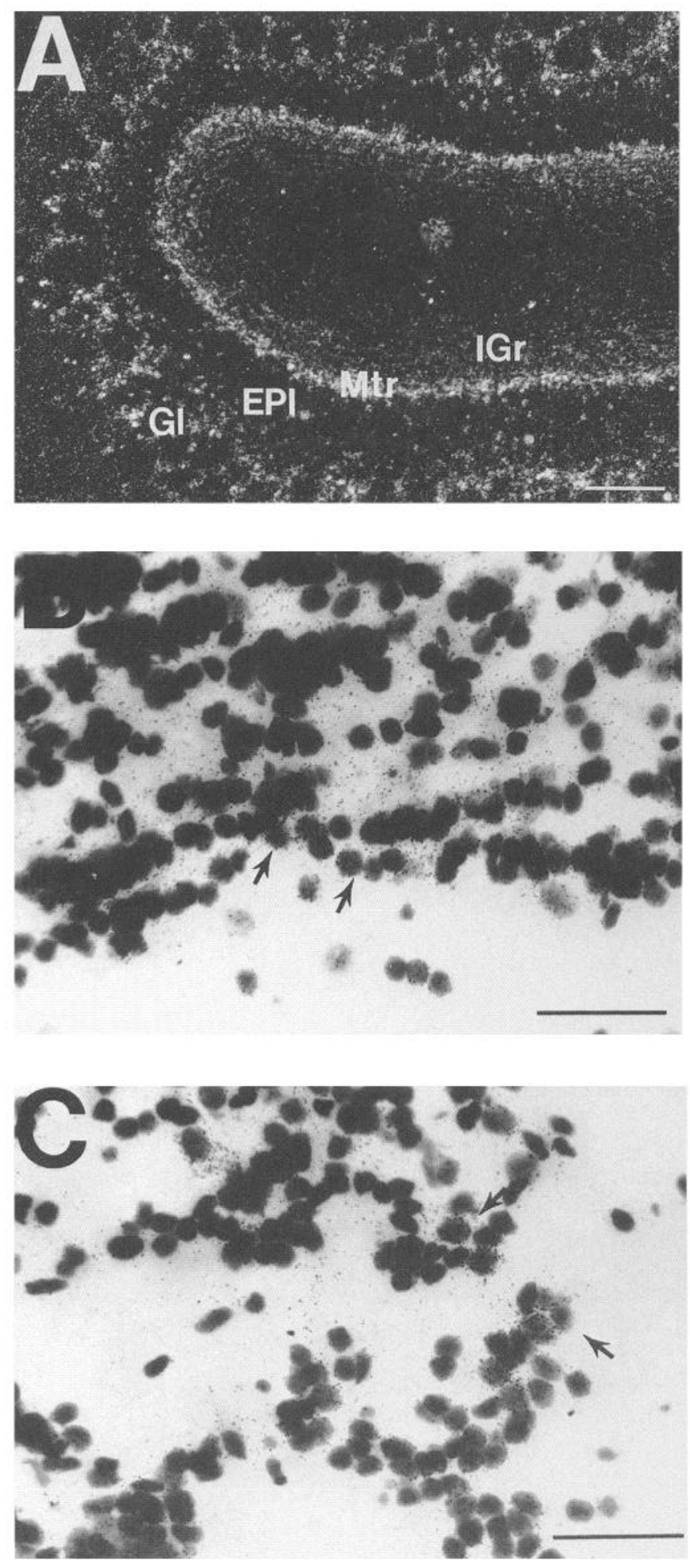

Figure 3. Expression of PAM mRNA in the olfactory bulb. A, Lowpower autoradiogram of a section hybridized with probe 1 demonstrates the presence of PAM mRNA in several layers of the olfactory bulb. Medium-high levels were found in the glomerular layer $(G l)$ of the olfactory bulb and the mitral cell layer $(M t r)$. Scattered cells in the external plexiform layer $(E P l)$ were also positive. Cells of the internal granular layer $(I G r)$ showed the weakest labeling. $B$ and $C$, High-power bright-field autoradiograms counterstained with cresyl violet show positively labeled cells (arrows) in the mitral layer $(B)$, and the glomerular layer $(C)$. Scale bars: $A, 500 \mu \mathrm{m} ; B$ and $C, 50 \mu \mathrm{m}$.
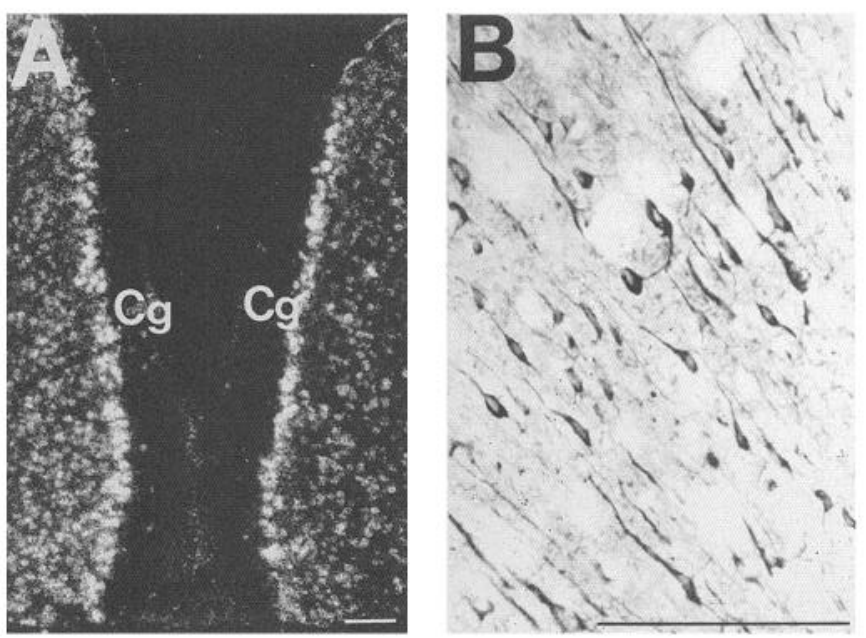

Figure 4. PAM expression in the anterior cingulate cortex. The pyramidal cells of the cingulate cortex $(\mathrm{Cg})$ show both high levels of PAM transcripts $(A)$ and a very robust PAM-like immunoreactivity (Ab 74) $(B)$, strongly suggesting that the PAM gene is highly expressed in these cells and translated into detectable protein. Exposure time of autoradiogram (probe 1) was $14 \mathrm{~d}$. Scale bars, $200 \mu \mathrm{m}$.

intense in comparison to Ammon's horn. At the microscopic level, labeling was seen principally over the pyramidal cell layer (Fig. $5 B$ ) and the granular cell layer of the dentate gyrus (Fig. $5 C$ ).

In the basal ganglia, numerous caudate putamen cells were positively labeled with the PAM cRNA probes, with moderate levels of PAM mRNA observed in both patch and matrix compartments (Fig. $6 A$ ). In the globus pallidus, neurons expressing PAM mRNA were fewer and more scattered than in the caudate putamen. The striatum and globus pallidus exhibited complex immunostaining patterns (Fig. $6 B$ ). Many positively stained medium-size neurons (Fig. $6 B$, solid arrow), probably striatal projection cells, could be observed throughout the caudate putamen, which additionally exhibited a dense fiber staining pattern. The PAM-like immunoreactive neurons in the globus pallidus were larger, more stellate shaped (Fig. $6 \mathrm{~B}$, open arrow), and surrounded by a diffuse network of immunoreactive fibers.

In the amygdala, the basolateral and central nuclei showed the highest concentration of PAM mRNA. The bed nucleus of the stria terminalis, known for its high content of neuropeptides, was among the more densely labeled structures of this region. In the basal forebrain, the lateral part of the septum expressed higher levels of PAM mRNA than its medial portion.

Diencephalon. The highest PAM mRNA levels of all brain areas were observed in the hypothalamus in the magnocellular elements of the paraventricular nucleus (PVN) and in the supraoptic nucleus (SON) (Fig. 7A). The magnocellular neurosecretory cells, which produce a variety of neuropeptides including vasopressin and oxytocin, showed intense labeling in both the PVN and the SON (Fig. 7B,F). Although both the oxytocinergic and vasopressinergic neurons were labeled positively, the latter seemed to show a denser labeling at the microscopic level. This was particularly apparent in the retrochiasmatic SON, a region consisting almost exclusively of vasopressin-containing neurons (Fig. $7 D, E$ ). The magnocellular neurons showed by far the strongest PAM-like immunostaining when the animals were pretreated with colchicine (Fig. $8 A$ ). Interestingly, in untreated perfused animals the SON and the PVN showed intense staining 

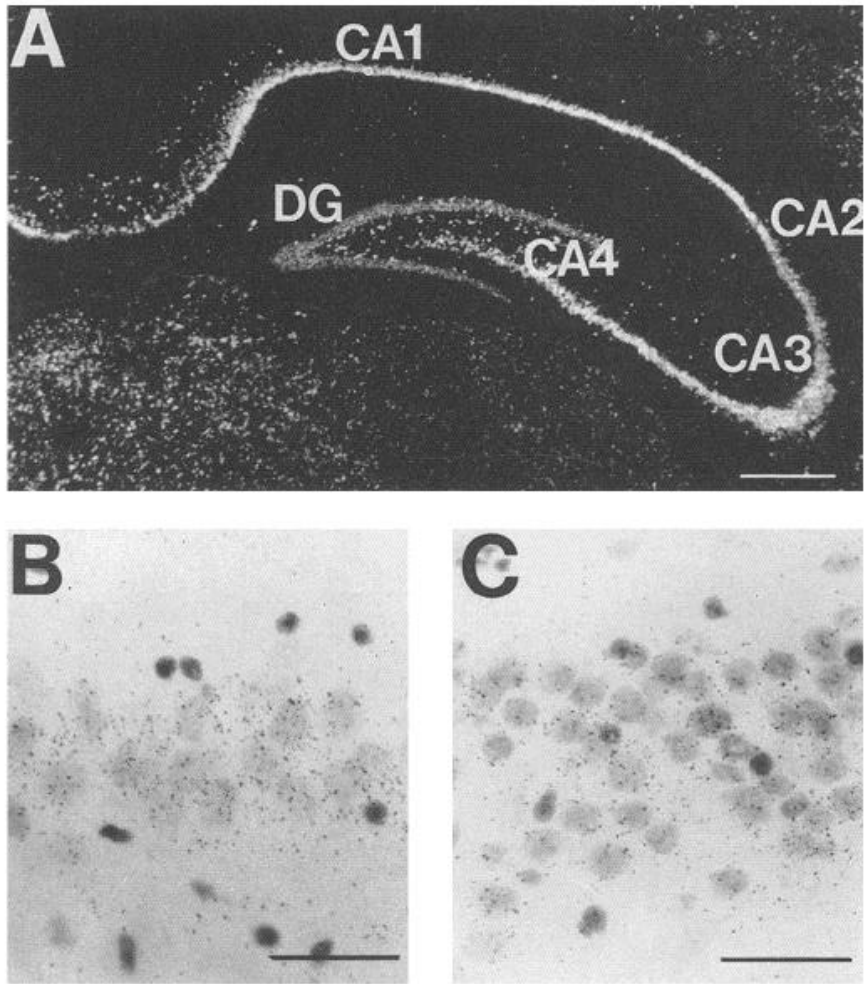

Figure 5. PAM expression in the hippocampal formation. A, PAM mRNA (detected with probe 2 ) was found highly expressed in all hippocampal regions including $C A 1, C A 2, C A 3, C A 4$, and at slightly lower levels in the granular cell layer of the dentate gyrus $(D G)$. Bright-field examination of autoradiograms counterstained with cresyl violet shows silver grains present over all pyramidal cells of Ammon's horn (CA1) $(B)$ and over the dentate granule cells $(C)$. Exposure time of autoradiograms was $21 \mathrm{~d}$. Scale bars: $A, 1 \mathrm{~mm} ; B$ and $C, 50 \mu \mathrm{m}$.

of fibers, suggesting that innervating fibers contain a PAM-like material (Fig. $8 B$ ). These PAM-positive inputs most likely originate from the $\mathrm{A} 1$ and $\mathrm{A} 2$ regions, which are known to produce neuropeptide Y (Sawchenko et al., 1985). The magnocellular neurons of the tuberomammillary nucleus in the posterior hypothalamus (Ericson et al., 1987), which express very high PAM mRNA levels (Fig. 2) and produce substance P, represent an alternative input. After preabsorbtion of the antibodies with 10 $\mu \mathrm{M}$ homologous antigen, all immunoreactivity vanished (Fig. $8 C$ ). All of the parvocellular subdivisions of the PVN contained many neurons showing a hybridization signal of intermediate density (Fig. $7 F$ ). In the median eminence, we observed strong immunostaining both in the internal and external layers. In the external layer, few cells expressing PAM mRNA were observed. Although numerous neurons in other hypothalamic areas expressed PAM, the levels of mRNA were severalfold lower than in the magnocellular neurons. The ventromedial and dorsomedial nuclei exhibited medium levels of PAM mRNA, while the anterior hypothalamic area and the lateral hypothalamus showed lower levels of PAM expression.

Many subregions of the thalamus expressed medium-high to high levels of PAM mRNA (Fig. 9A). A rostrocaudal gradient was observed, with the anterior thalamic nuclei exhibiting a higher density of PAM mRNA expression. The anterodorsal and anteroventral nuclei contained numerous intensely labeled neurons. Previous studies have demonstrated that the rat thal-
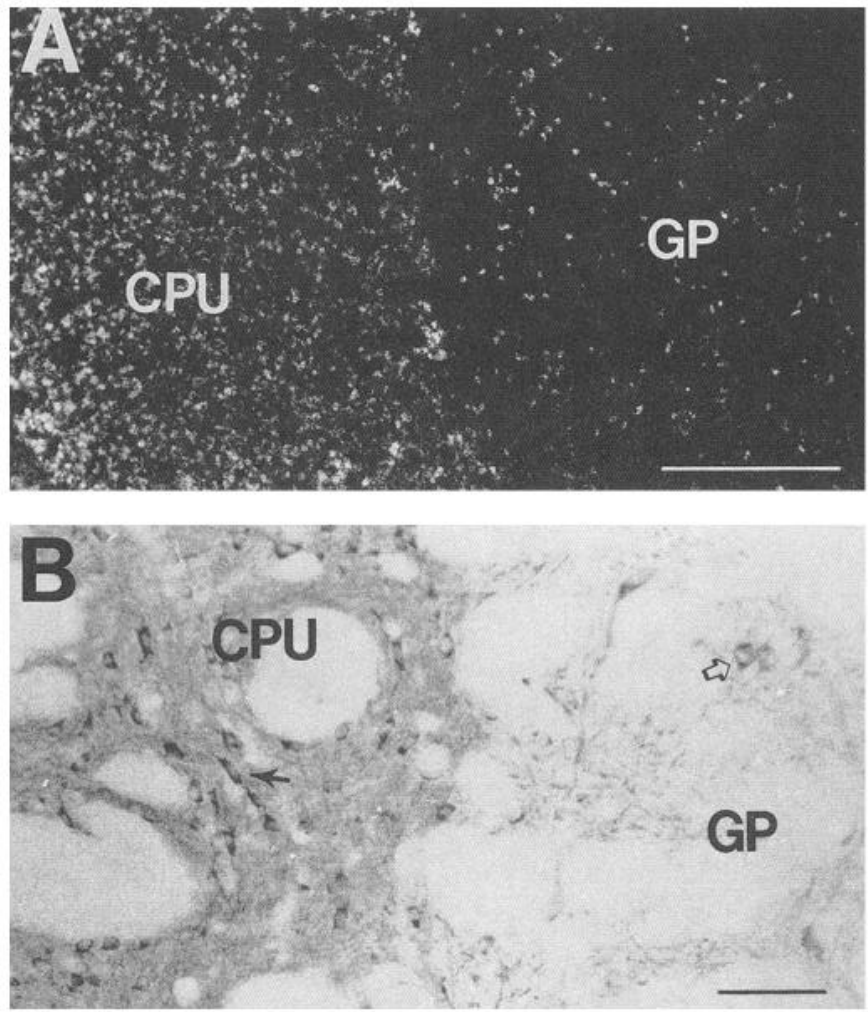

Figure 6. Expression of PAM in caudate putamen $(C P V)$ and globus pallidus $(G P)$. $A$, While the PAM mRNA-containing neurons in the striatum were numerous and found in all regions, the globus pallidus had far fewer neurons expressing PAM mRNA, and their distribution was more patchy (exposure time of autoradiogram hybridized with probe 2 was $21 \mathrm{~d})$. The immunostaining of the caudate putamen $(B)$ using $A B$ 74 revealed numerous medium-size immunoreactive neurons (solid arrow), most likely the striatal projection neurons, and a strong diffuse fiber staining pattern. In the globus pallidus, immunoreactivity was sparse and mainly confined to medium-size stellate-shaped cells (open arrow). Scale bars: $A, 1 \mathrm{~mm} ; B, 50 \mu \mathrm{m}$.

amus is rich in CCK mRNA (Siegel and Young, 1985; Ingram et al., 1989).

In the habenula, where amidated neuropeptides such as substance $\mathrm{P}$ and neurokinin $\mathrm{B}$ are prevalent (Siegel and Young, 1985; Burgunder and Young, 1989), we observed a heterogeneous distribution pattern for PAM mRNA. While the lateral habenula contained scattered PAM mRNA-expressing cells, virtually all cells of the medial habenula expressed PAM mRNA, with the ventral portion being the most intensely labeled subregion (Fig. 9B).

Mesencephalon. In the midbrain, the superior and inferior colliculi expressed PAM mRNA, with the latter showing a denser labeling (Fig. 2). Other areas exhibiting medium to mediumhigh levels of PAM mRNA included the interpeduncular nucleus, the ventral tegmental area, the pars compacta of the substantia nigra, periaqueductal gray, the medium and dorsal raphe nuclei, and the Edinger-Westphal nucleus (Table 1).

Pons and medulla. Several brainstem nuclei exhibited medium to medium-high levels of PAM mRNA (Fig. 9C). These included the parabrachial nucleus, pontine nuclei, inferior olive, nucleus of the solitary tract (NTS), the vestibular and cochlear nuclei, and the dorsal motor nucleus of the vagus (Table 1). Other areas of low to medium density included the facial nu- 
Figure 7. Expression of PAM in the hypothalamo-neurohypophysial system. $A$, The magnocellular neurons of the supraoptic nucleus $(S O N)$ and paraventricular nucleus $(P V N)$ exhibited the strongest signal of all hypothalamic nuclei when hybridized with the PAMspecific riboprobe 1 (exposure time, 14 d). The robust signal over magnocellular SON neurons $(B)$ was completely blocked if sections were RNase pretreated $(C)$ or probed with sense-strand RNA (exposure time, $7 \mathrm{~d}$ ). In the retrochiasmatic nucleus, which consists almost exclusively of vasopressin-producing neurons, both a strong hybridization signal $(D)$ and intense PAM-like immunostaining $(E)$ were observed (probe $1, \mathrm{Ab} 69$ ). In the PVN $(F)$, all subgroups expressed PAM RNA ( $P M$, posterior magnocellular group; $d p$, dorsal parvocellular; $l p$, lateral parvocellular; $m p$, medial parvocellular), with the $P M$ subgroup having the strongest signal followed by the $m p$ group. Both $P M$ and $m p$ cell groups produce a variety of $\alpha$-amidated peptides, including $\mathrm{CRH}$ in the $m p$ group. $O T$, Optic tract; $A H C$, central anterior hypothalamic area. *, Blood vessel. Scale bars: $A$, $1 \mathrm{~mm} ; B-F, 100 \mu \mathrm{m}$.
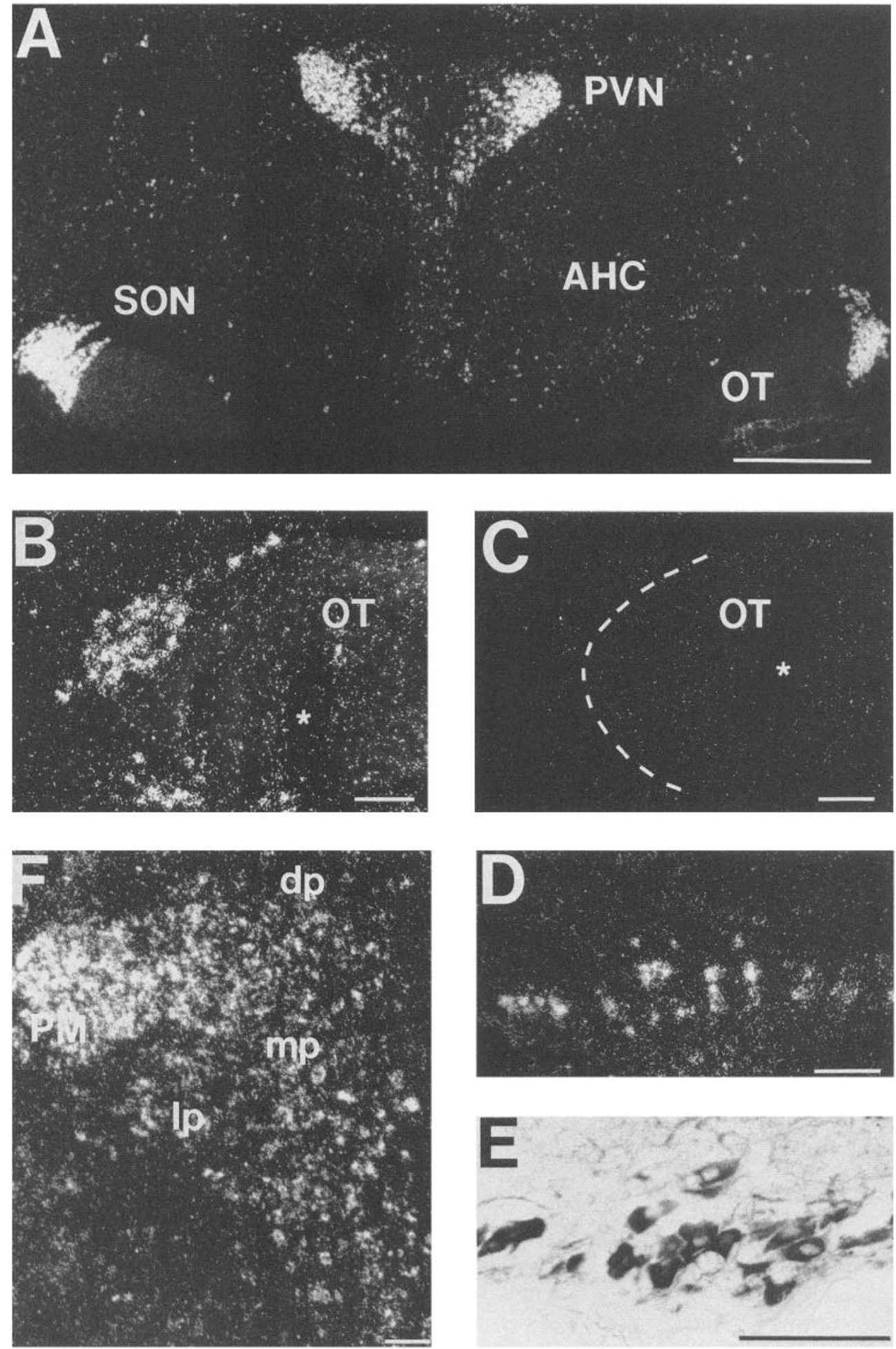

cleus, lateral reticular nuclei, raphe nuclei, and the gray matter of the spinal cord.

Expression of PAM in non-neuronal tissue. High levels of PAM RNA transcripts were detected in the ependymal cells lining the lateral ventricles (Fig. 10A). The expression level of the PAM gene in ependymal cells was very region specific. Relatively strong hybridization signals were obtained in the ependymal layer of the lateral ventricle bordering the corpus striatum
(Fig. 10A,B). When examined by immunocytochemistry, these ependymal cells exhibited only very faint staining, which was difficult to distinguish from nonspecific staining (data not shown); a high rate of secretion of PAM from these cells could explain these results. Other ependymal cells including those lining the third and fourth ventricles and the cerebral aqueduct did not show any detectable PAM mRNA.

The outer and inner layers of the walls of several brain arteries 
expressed medium levels of the PAM RNA transcripts. For example, in sections through the anterior cerebral artery many cells in the adventitial layer were observed that expressed relatively high levels of PAM mRNA (Fig. 10C,D). In the intima, fewer and less intensely labeled cells were detected. Due to the poor morphological tissue preservation following in situ hybridization treatment, an unambiguous histological characterization of these cells was impossible, even in cresyl violet-counterstained sections (Fig. 10D). The PAM-expressing cells of the intima were identified as endothelial cells. Presently, we can only speculate on the nature of the PAM-expressing cells in the adventitia as being fibroblasts, glia, or tissue macrophages. No positive PAM-like immunoreactivity was detected in arterial walls with any of the PAM antibodies, suggesting that potential PAM-derived peptidergic products in these cells are present at very low levels due to rapid secretion or inefficient translation of the mRNA.

\section{Discussion}

Sites of expression of the PAM gene have been mapped in adult rat brain by in situ hybridization. PAM RNA transcripts were found in virtually all major brain areas with the exception of the cerebellum. A broad distribution of PAM in the CNS is consistent with the role of this enzyme in the posttranslational modification of all $\alpha$-amidated neuropeptides and the presence of amidated neuropeptides in all major brain areas. The distribution of amidation activity in the CNS previously reported (Emeson, 1984; Eipper et al., 1985; Meng and Tsou, 1988) matches closely the distribution of PAM mRNA observed here. In general, areas expressing high levels of PAM mRNA, such as SON, hippocampus, and neocortex, also expressed strong PAM-like immunostaining. However, for mapping sites of PAM expression we have relied on in situ hybridization more than on immunocytochemistry, since the latter technique (1) often requires colchicine pretreatment for visualization of neuronal perikarya, (2) fails to detect cells that synthesize and secrete but do not store large amounts of PAM, and (3) is dependent on the appropriate tissue pretreatment and fixation paradigm. This is underscored by a recent report on the immunocytochemical localization of PAM in neuronal tissues. While our immunocytochemical findings based on formaldehyde-fixed tissue are largely in agreement, PAM-like immunoreactivity was demonstrated in ependymal and glial tissue with the appropriate tissue preservation (Rhodes et al., 1990).

In an attempt to correlate sites of PAM expression with production of amidated peptides, we have focused on selected areas with either high or low levels of PAM expression. Highest levels of PAM mRNA and PAM-like immunoreactivity were found in the hypothalamus, hippocampus, and cortical areas. Interestingly, the magnocellular hypothalamic neurons of the SON and PVN, well known for their synthesis of a variety of neuropeptides including the classical neuroendocrine hormones vasopressin and oxytocin (Swanson, 1987), exhibited the highest cellular concentration of PAM mRNA throughout the rat brain. The same cells expressed strong positive immunostaining, suggesting the presence of PAM-like immunoreactive material. Taken together, the immunocytochemical and in situ hybridization data suggest that PAM is expressed at high levels in these neuroendocrine cells. High levels of PAM expression might be necessary for production of the large amounts of the many $\alpha$-amidated peptides synthesized in these cell groups (vasopressin, oxytocin, CRH, cholecystokinin, galanin, opioids).
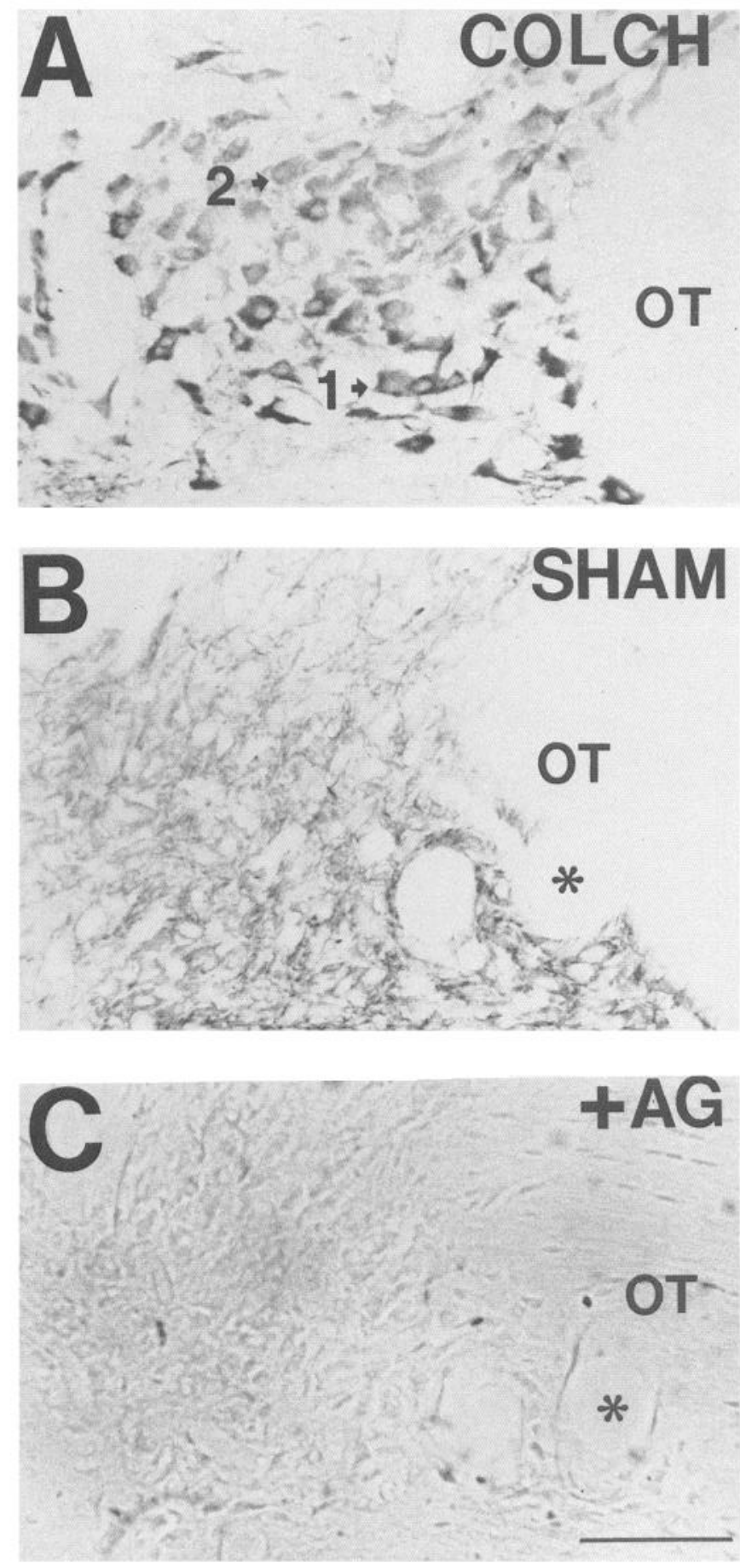

Figure 8. PAM-like immunoreactivity in the SON (Ab 74). A, Perfused tissue sections from animals pretreated with colchicine exhibited strong immunostaining of magnocellular perikarya. A gradient was observed, with the ventral cell group (arrow 1, mainly vasopressinergic) expressing stronger PAM-like immunoreactivity than the dorsal group (arrow 2, mainly oxytocinergic). B, Fiber-like staining pattern of the SON region in untreated animals suggesting innervating fibers express PAM. These fibers most likely represent the afferent fibers originating at $A 1$ and $A 2$ (also known to contain the amidated neuropeptide $\mathrm{Y}$ ) or the substance $\mathrm{P}$-containing tuberomammillary nucleus, which expresses high PAM mRNA levels. $C$, Preabsorption of the antisera with a $1 \mu \mathrm{M}$ concentration of antigen eliminated all staining completely. $O T$, Optic tract. Scale bar, $100 \mu \mathrm{m}$. 

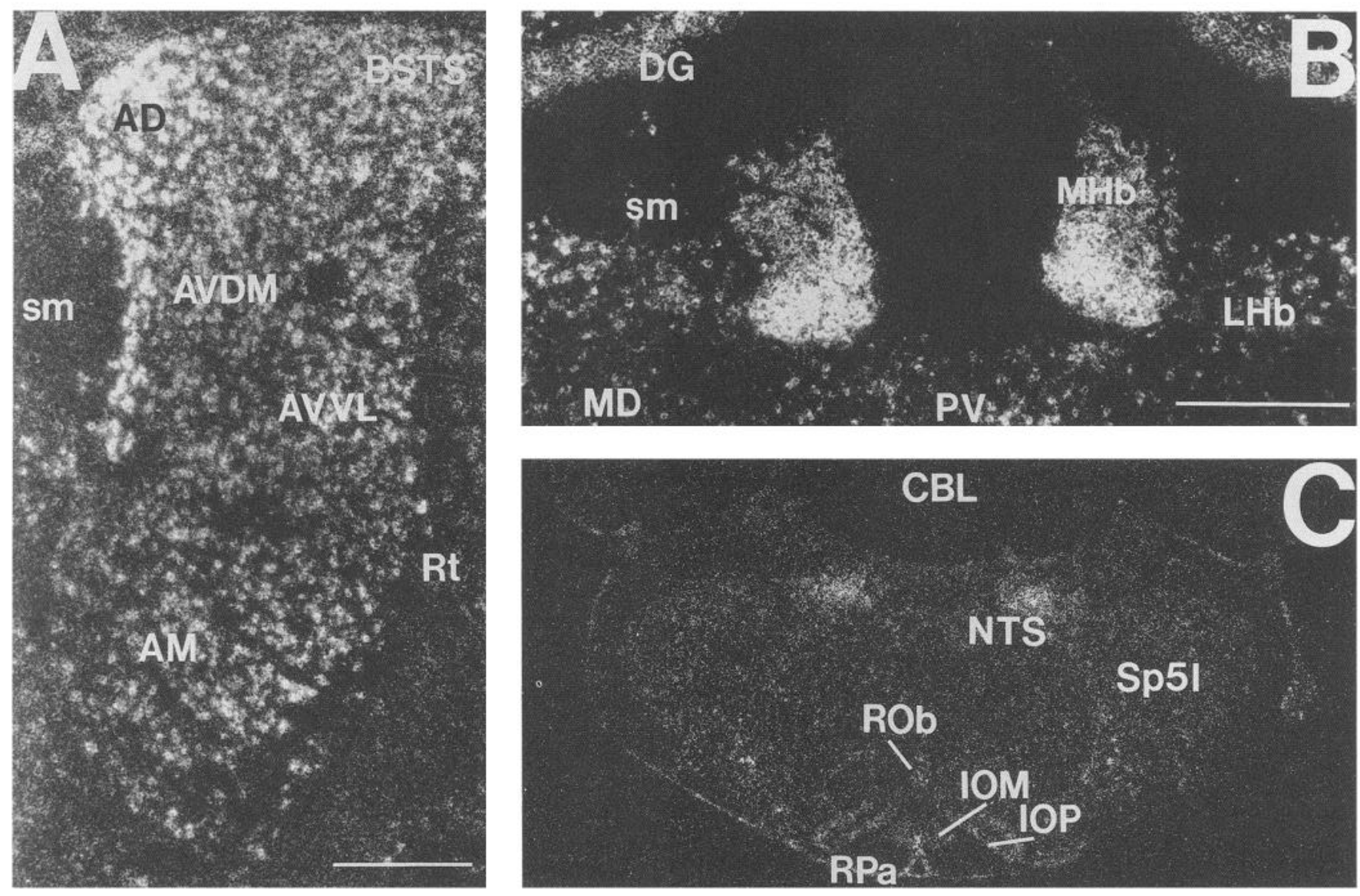

Figure 9. Dark-field autoradiograms of PAM mRNA localization in various brain regions using probe 2. $A$, Several thalamic subregions contain high levels of PAM mRNA. The anterodorsal nucleus contains the highest concentrations of PAM mRNA, followed by medium high levels in the anteroventral thalamus (exposure time, 6 weeks). $B$, The medial habenula expressed high concentration of PAM mRNA. Fewer scattered PAMexpressing cells are also present in the lateral habenula. $C$, In the brain stem, the NTS and inferior olive (known for their high content of CRH) are among the highest PAM mRNA-expressing nuclei (exposure time of x-ray autoradiogram, $2 \mathrm{~d}$ ). $A D$, anterodorsal thalamic nucleus; $A M$, anteromedial thalamic nucleus; $A V D M$, anteroventral thalamic nucleus, dorsomedial part; $A V V L$, anteroventral thalamic nucleus, ventrolateral part; $B S T S$, bed nucleus of stria terminalis; $C B L$, cerebellum; $D G$, dentate gyrus; $I O M$, inferior olive, medial nucleus; $I O P$, inferior olive, principal nucleus; $L H b$, lateral habenula; $M D$, mediodorsal thalamic nucleus; $M H b$, medial habenula; $N T S$, nucleus of the solitary tract; $P V$, periventricular thalamic nucleus; $R O b$, raphe obscurus nucleus; $R P a$, raphe pallidus nucleus; $R t$, reticular thalamic nucleus; $s m$, stria medullaris thalamus; $S p 5 l$, interpolar spinal trigeminal nucleus. Scale bars, $500 \mu \mathrm{m}$.

Previous studies have demonstrated that PAM enzymes are located within secretory granules and secreted along with peptide products (Mains and Eipper, 1984; Glembotski, 1985; Wand et al., 1985). The granular pattern of the immunostaining and the accumulation of immunoreactive material in colchicinepretreated animals, which blocks axonal transport of granules, strongly suggest an intragranular localization for PAM. In the magnocellular nuclei, one would therefore expect the enzyme to be transported to the neural lobe of the pituitary for secretion together with vasopressin, oxytocin, and other peptide products into the portal blood. Indeed, PHM and PAL were both purified from the bovine neurointermediate pituitary (Murthy et al., 1987; Perkins et al., 1990) and activity is found in serum (Eipper et al., 1985). However, further detailed studies on the ultrastructural level are necessary to establish the subcellular distribution of different PAM proteins.

Although both oxytocinergic and vasopressinergic magnocellular neurons produce a variety of amidated peptides, we observed a difference in the intensity of PAM immunostaining in the SON. In general, the ventral portion of the nucleus, richer in vasopressin-containing cells, exhibited a stronger immunostaining than the dorsal region, where oxytocinergic cells predominate. This was further supported by the in situ results, where vasopressin-synthesizing neurons appeared to have a slightly higher grain density, although no quantitative analysis was performed. Strong PAM-like immunoreactivity was observed in the retrochiasmatic nucleus, which consists almost exclusively of vasopressin-synthesizing cells. The observed difference could be explained by distinct forms of PAM being expressed by each cell type, having different affinities to our antibody, or different concentrations of each PAM form being expressed. More detailed studies using antibodies specific for different PAM forms could address these questions.

SON from non-colchicine-treated rats showed numerous immunoreactive fibers surrounding the weakly stained magnocellular neurons. These PAM-positive fibers do not derive from the magnocellular neurons themselves but represent terminals of innervating fibers. Innervation of the SON and PVN by afferent catecholaminegic fibers containing amidated neuropeptides (Sawchenko et al., 1985) could provide a rationale for the 

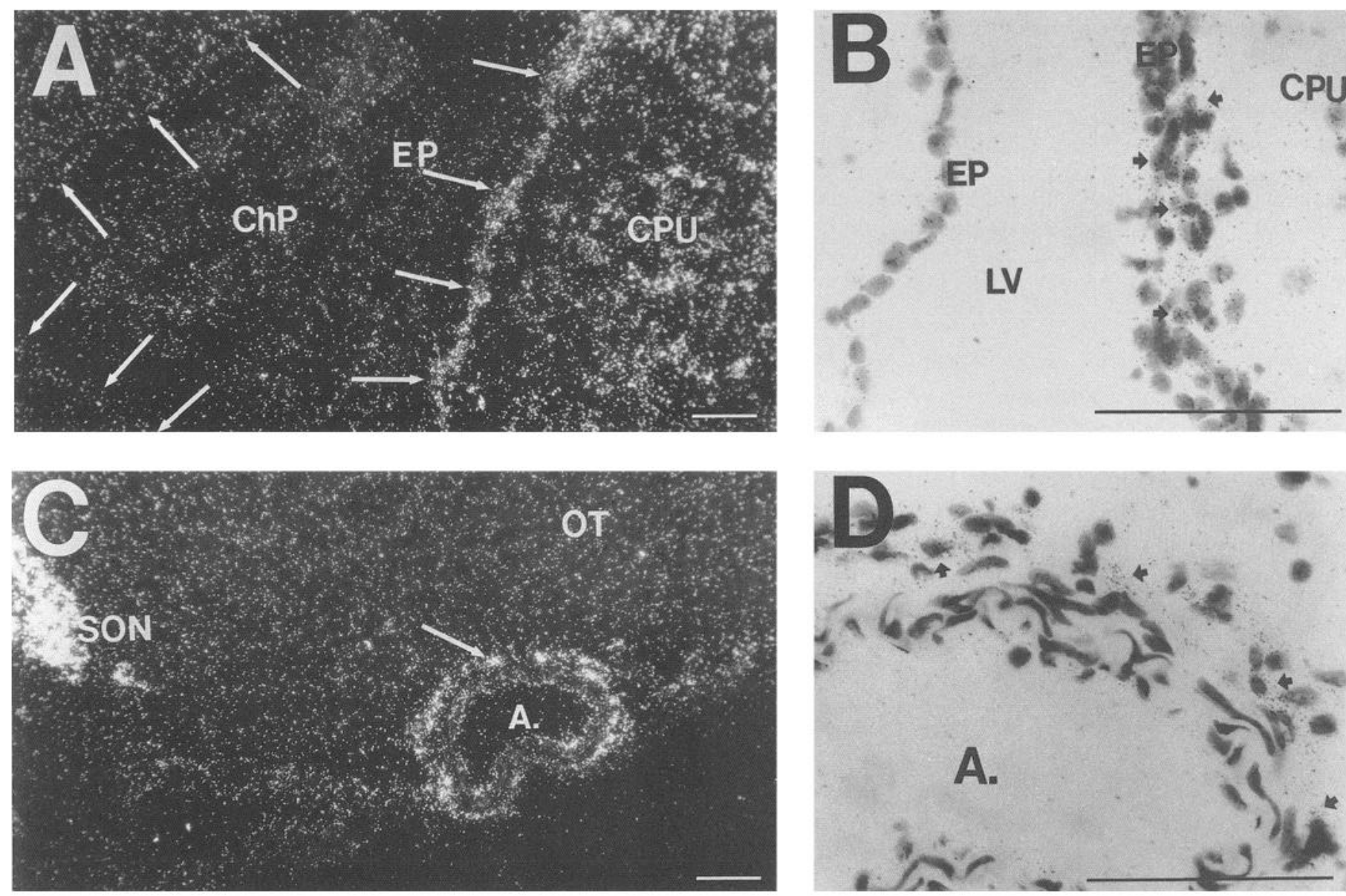

Figure 10. PAM mRNA in non-neuronal tissue. $A$, Dark-field autoradiogram of PAM mRNA localization in the ependymal cell layer ( $E P$ ) of the anterior horn of the lateral ventricle. The expression of PAM in ventricular ependyma (white arrows) seems to be very region specific. Note that only the ependymal cells neighboring the striatum (CPU) express high levels of PAM. The other ependymal cells and cells of the choroid plexus $(C h P)$ do not express high levels of PAM. B. Bright-field autoradiogram counterstained with cresyl violet at higher magnification. A positive hybridization signal is observed over many but not all ependymal cells of the ventricular side bordering the striatum. Note the absence of specific hybridization over cells on the other ventricular border. $C$, In several brain arteris, PAM mRNA-expressing cells were found. Shown here is the anterior cerebral artery $(A)$ with positively labeled cells mainly in the adventitial layer (white arrow), and a few in the intima. $D$, Bright-field autoradiogram demonstrating the presence of PAM mRNA in adventitia cells (arrows) of the arterial wall. Using probe 1, all autoradiograms had an exposure time of 6 weeks. $L V$, lateral ventricle; $O T$, optic tract. Scale bar, $100 \mu \mathrm{m}$.

presence of PAM in these nerve endings. Innervation of the SON by histaminergic neurons of the tuberomamillary nucleus, which contains substance $\mathbf{P}$ and galanin, has been reported recently (Ericson et al., 1987). We found high levels of PAM mRNA in this cell group, which contributes PAM-like immunoreactive fibers. The high levels of PAM expression in the hypothalamic-neurohypophysial system with its well-characterized physiological role in osmotic homeostasis could provide an ideal model system in which to study the regulation of PAM expression in comparison with its substrates. In fact, preliminary data from our laboratory suggest that PAM mRNA levels are increased in the SON following chronic osmotic challenge (M. K.-H. Schafer, unpublished observation), which is in concordance with the established increases of vasopressin and oxytocin synthesis.

In the PVN, which comprises several morphologically heterogeneous cell groups known to express a variety of different neuropeptides (Swanson, 1987), the highest levels of PAM mRNA were seen in the magnocellular neurons. In addition, the moderate levels of PAM expression in the parvocellular cell groups, although much lower than in the neighboring magnocellular cells, let them stand in contrast to the numerous slightly PAM-positive neurons in the hypothalamus. Particularly prominent are the CRH-producing neurons in the medial parvocellular subdivision, which project to the outer layer of the median eminence and release their peptide products to the portal blood to activate POMC synthesis in the anterior lobe (Antoni et al., 1983). Expression of CRH in the hypothalamic pituitary adrenal stress axis is increased following adrenalectomy (Swanson and Simmons, 1989), and a recent report by Grino and coworkers suggests that PAM expression is regulated by glucocorticoids in parallel with CRH (Grino et al., 1990). In vitro studies demonstrated the coordinate regulation of PAM and POMC gene expression in AtT-20 cells (Thiele et al., 1989), suggesting a tightly linked regulation of enzyme and substrate expression on the transcriptional level.

Additional areas showed a strong correlation between PAM distribution and that of known $\alpha$-amidated peptides. In the neocortex, PAM distribution closely matches the expression of CCK, with high concentration of both in layers two, three, five, 
and six (Siegel and Young, 1985; Ingram et al., 1989). The inferior olivary complex, known for its CRH content (Cummings, 1989), and the NTS and bed nucleus of stria terminalisthe latter two producing a variety of amidated peptides-also exhibited high levels of PAM expression. However, several areas not known for their synthesis of $\alpha$-amidated peptides exhibited high levels of PAM mRNA, including the hippocampal formation. Although a high concentration of CCK mRNA in the hippocampal formation has been reported, it was found to be mainly present in the CA-3 region (Siegel and Young, 1985; Ingram et al., 1989). Also, in the above-described regions of the ventricular ependyma where high levels of PAM were identified, $\alpha$-amidated peptides have not yet been clearly identified, although the amidated peptide endothelin 1 represents a potential substrate for PAM (Yanagisawa and Masaki, 1989). A similar situation occurs in the rat atrium where high levels of PAM are not accompanied by expression of known amidated peptides (Markosian et al., 1989; Ouafik et al., 1989; Stoffers et al., 1989). One could speculate on the presence of amidated peptides yet to be discovered in these areas. Alternatively, PAM may have additional functions other than catalyzing amidation of peptides.

A similar situation is observed for PAM expression in nonneuronal tissues in the brain. At least to our knowledge, $\alpha$-amidated peptides have not yet been isolated from ependyma or brain arteries. Therefore, the expression of PAM in these cells may indicate the presence of such peptides and may be the starting point for an exciting endeavor into the search for such peptides. Alternatively, one must consider the possibility that PAM mRNA may not be translated into protein. However, recent reports by others have indicated strong PAM immunoreactivity in ependymal cells, supporting our in situ data (Rhodes et al., 1990). The lack of strong immunostaining of ependymal cells in our study could be due to inadequate tissue pretreatment and perfusion, the importance of which for PAM immunoreactivity has been demonstrated by these authors. Several endothelial cell lines and endothelial cells in bovine hypophyseal arteries express PAM (V. May and K. M. Braas, personal communication). The expression of PAM in non-neuronal tissue is supported by a growing body of literature, suggesting the expression of PAM mRNA and PAM immunoreactivity together with other processing enzymes, such as carboxypeptidase E (Vilijin et al., 1989), and neuropeptides in neuroglial cultures, including substance P (Michel et al., 1986) and somatostatin and proenkephalin (Vilijin et al., 1988; Shinoda et al., 1989). While PAM-immunoreactive astrocytes in cerebellar white matter have bcen reportcd (Rhodes et al., 1990), our in situ hybridization results do not show detectable levels of PAM mRNA in this particular region, even after longer exposure times to autoradiographic emulsion. This could be explained by a low-level expression of PAM mRNA in astrocytes below the sensitivity of our in situ assay.

While we have demonstrated the widespread expression of PAM in normal adult rat brain, we have not addressed the complex molecular structure of the PAM gene and its multiple RNA and peptide forms. Although it is known from previous studies that several PAM mRNA forms exist, their detailed distribution in the CNS is not known. The two major forms of PAM mRNA isolated from rat heart, $3.8 \mathrm{~kb}$ and $4.2 \mathrm{~kb}$ in size, are thought to be the major forms in the CNS (Braas et al., 1989; Stoffers et al., 1991). Since the alternative splicing of the PAM gene is subject to tissue-specific and developmental regulation, it may have functional significance (Ouafik et al., 1989). In order to address these questions in the CNS, RNA probes specific for the different PAM RNAs could be used in future studies.

Further diversity in PAM expression can be generated by endoproteolytic processing of the various PAM protein precursors. In the bovine neurointermediate pituitary, the PAM precursor is cleaved into soluble PHM and PAL catalytic domains (Murthy et al., 1987; Perkins et al., 1990). In the rat brain, a significant amount of the PAM activity remains membrane associated (Braas et al., 1989). Domain-specific antibodies can be used to determine whether PHM and PAL exhibit similar distribution patterns in various brain regions.

We have shown a widespread, but distinctly heterogenous, pattern of PAM expression in the rat CNS and demonstrated the overall presence of the amidating enzyme in neuropeptiderich brain regions. Recently, the distribution of another neuropeptide processing enzyme, carboxypeptidase H (EC 3.4.17.10), also known as CPE, in the CNS was reported (Bondy et al., 1989; Birch et al., 1990; Lynch et al., 1990; MacCumber et al., 1990). CPE removes basic amino acid residues from the carboxy-terminal end of protein precursor fragments previously cleaved by endoproteases and generates the carboxy-terminal Gly residue required by PHM (Fricker, 1988). When comparing the distribution of the mRNAs for these two enzymes, in general we observed a good overlap of PAM and CPE mRNA expression in most brain regions. The major exception was the cerebellum, where a dense labeling was seen for CPE mRNA (MacCumber et al., 1990) and PAM mRNA was absent. This surprising finding would suggest that theoretically the processing of protein precursors of amidated neuropeptides, which generates amidated forms in other tissues, cannot yield amidated products due to the absence of PAM. Although the presence of neuropeptides in the cerebellum is poorly characterized, one such scenario could be envisioned for the expression of proenkephalin in cerebellar Golgi II cells (Harlan et al., 1987). The processing of proenkephalin in adrenal medulla can generate two amidated peptides, metorphamide and amidorphin (for review, see Hollt, 1986). Since we have not observed any PAM mRNA or PAM-like immunoreactivity in Golgi II cells, one could speculate that if the proenkaphalin precursor is properly cleaved, nonamidated forms of amidorphin and metorphamide should be present in this cell type. The alternative possibility that the cerebellum contains another amidating enzyme is unlikely, since previous studies failed to measure significant amounts of amidation activity in the cerebellum (Eipper et al., 1985; Meng and Tsou, 1988). Whether PAM is also completely absent in afferent neurons and terminals in the cerebellum will require a more careful immunohistochemical investigation.

While the detection of the $\alpha$-amide moiety of peptides in the chemical assay of Tatemoto and Mutt (1980) has been invaluable in the isolation of novel neuropeptides, the cellular distribution of PAM may further aid as an "histochemical assay" to identify brain areas in which novel $\alpha$-amidated peptides play a functional role.

\section{References}

Antoni FA, Palkovits M, Makara GB, Linton EA, Lowry PJ, Kiss JZ (1983) Immunoreactive corticotropin-releasing hormone (CRF) in the hypothalamo-infundibular tract. Neuroendocrinology 36:415-432. Birch NP, Rodriquez C, Dixon JE, Mezey E (1990) Distribution of carboxypeptidase $\mathrm{H}$ messenger RNA in rat brain using in situ hy- 
bridization histochemistry: implications for neuropeptide biosynthesis. Mol Brain Res 7:53-59.

Bondy CA, Whitnall MH, Brady LS (1989) Regulation of carboxypeptidase $\mathrm{H}$ gene expression in magnocellular neurons: response to osmotic stimulation. Mol Endocrinol 3:2086-2092.

Braas KM, Stoffers DA, Eipper BA, May V (1989) Tissue specific expression of rat peptidylglycine $\alpha$-amidating monooxygenase activity and mRNA. Mol Endocrinol 3:1387-1398.

Burgunder JM, Young WS III (1989) Neurokinin B and substance P genes are co-expressed in a subset of neurons in the rat habenula. Neuropeptides 13:165-169.

Cummings SL (1989) Distribution of corticotropin-releasing factor in the cerebellum and precerebellar nuclei of the cat. J Comp Neurol 289:657-675.

Eipper BA, Mains RE (1988) Peptide $\alpha$-amidation. Annu Rev Physiol 50:333-344.

Eipper BA, Myers AC, Mains RE (1985) Peptidyl-glycine $\alpha$-amidation activity in tissues and serum of the adult rat. Endocrinology 116: 2497-2504.

Eipper BA, Park LP, Dickerson IM, Keutmann HT, Thiele EA, Rodriguez H, Schoefield PR, Mains RE (1987) Structure of the precursor to an enzyme mediating COOH-terminal amidation in peptide biosynthesis. Mol Endocrinol 1:777-790.

Eipper BA, May V, Braas KM (1988) Membrane-associated peptidylglycine $\alpha$-amidating monooxygenase in the heart. J Biol Chem 263:8371-8379.

Emeson RB (1984) Hypothalamic peptidyl-glycine alpha-amidating monooxygenase: preliminary characterization. J Neurosci 4:2604 2613.

Ericson H, Watanabe T, Kohler C (1987) Morphological analysis of the tuberomammillary nucleus in the rat brain: delineation of subgroups with antibody against L-histidine decarboxylase as a marker. J Comp Neurol 263:1-24.

Fricker LD (1988) Carboxypeptidase E. Annu Rev Physiol 50:309321.

Glauder J, Ragg H, Rauch J, Engels JW (1990) Human peptidylglycine $\alpha$-amidating monooxygenase: cDNA, cloning and functional expression of a truncated form in COS cells. Biochem Biophys Res Commun 169:551-558.

Glembotski CC (1985) Further characterization of the peptidyl- $\alpha$ amidating enzyme in rat anterior pituitary secretory granules. Arch Biochem Biophys 241:673-683.

Grino M, Guillaume V, Boudouresque F, Devolx C, Maltese J, Oliver C (1990) Glucocorticoids regulate peptidylglycine $\alpha$-amidating monooxygenase gene expression in the rat hypothalamic paraventricular nucleus. Mol Endocrinol 4:1613-1619.

Harlan RE, Shivers BD, Romano GJ, Howells RD, Pfaff DW (1987) Localization of preproenkephalin in the rat brain and spinal cord by in situ hybridization. J Comp Neurol 258:159-184.

Hollt V (1986) Opioid peptide processing and receptor selectivity. Annu Rev Pharmacol Toxicol 26:59-77.

Ingram SM, Krause RG, Baldino F Jr, Skeen LC, Lewis ME (1989) Neuronal localization of cholecystokinin mRNA in the rat brain by using in situ hybridization histochemistry. J Comp Neurol 287:260272.

Katapodis AG, Ping D, May SW (1990) A novel enzyme from bovine neurointermediate pituitary catalyzes dealkylation of $\alpha$-hydroxyglycine derivatives, thereby functioning sequentially with peptidylglycine $\alpha$-amidating monooxygenase in peptide amidation. Biochemistry 29 : 6115-6120.

Kato I, Yonekura H, Yamamoto H, Okamoto H (1990) Isolation and functional expression of pituitary peptidylglycine $\alpha$-amidating enzyme mRNA. A variant lacking the transmembrane domain. FEBS Lett 269:319-323.

Lynch DR, Braas KM, Hutton JC, Snyder SH (1990) Carboxypeptidase $\mathrm{E}$ (CPE): immunocytochemical localization in the rat central nervous system and pituitary gland. J Neurosci 10:1592-1599.

MacCumber MW, Snyder SH, Ross CA (1990) Carboxypeptidase E (enkephalin convertase): mRNA distribution in rat brain by in situ hybridization. J Neurosci 10:2850-2860.

Mains RE, Eipper BA (1984) Secretion and regulation of two biosynthetic enzyme activities, peptidyl-glycine $\alpha$-amidating monooxygenase and a carboxypeptidase, by mouse pituitary corticotropic tumor cells. Endocrinology 115:1683-1690.

Mains RE, Bloomquist BT, Eipper BE (1991) Manipulation of neu- ropeptide biosynthesis through the expression of antisense RNA for peptidylglycine $\alpha$-amidating monooxygenase. Mol Endocrinol 5:187193.

Markosian KA, Paitian NA, Abramian KS, Nalbandian RM (1989) Peptidylglycine alpha-amidating monooxygenase from bovine heart atrium secretory granules and adrenal chromaffin granules. Biokhimiia 54:2046-2053.

Meng F, Tsou K (1988) Biochemical mapping of peptidyl-glycine alpha-amidation activity in the rat CNS. J Neurochem 50:1352-1355.

Michel JP, Sakamolo N, Bouvier R, Tommasi M, Pearson J (1986) Substance P-immunoreactive astrocytes related to deep white matter and striatal blood vessels in human brain. Brain Res 377:383-397.

Mizuno K, Ohsuye K, Wada Y, Fuchimura K, Tanaka S, Matsuo H (1987) Cloning and sequence of cDNA encoding a peptide C-terminal alpha-amidating enzyme from Xenopus laevis. Biochem Biophys Res Commun 148:546-552.

Murthy AS, Keutmann HT, Eipper BA (1987) Further characterization of peptidylglycine alpha-amidating monooxygenase from bovine neurointermediate pituitary. Mol Endocrinol 1:290-299.

Ohsuye K, Kitano K, Wada Y, Fuchimura K, Tanaka S, Mizuno K, Matsuo H (1988) Cloning of cDNA encoding a new peptide C-terminal alpha-amidating enzyme having a putative membranespanning domain from Xenopus laevis skin. Biochem Biophys Res Commun 150:1275-1281.

Ouafik L'H, May V, Keutmann HT, Eipper BA (1989) Developmental regulation of peptidylglycine alpha-amidating monooxygenase (PAM) in rat heart atrium and ventricle. Tissue-specific changes in distribution of PAM activity, mRNA levels, and protein forms. J Biol Chem 264:5839-5845.

Perkins SN, Husten EJ, Eipper BA (1990) The 108-kDa peptidylglycine-amidating monooxygenase precursor contains two separable enzymatic activities involved in peptide amidation. Biochem Biophys Res Commun 171:926-932.

Rhodes CH, Xu RY, Angeletti RH (1990) Peptidylglycine alpha-amidating monooxygenase (PAM) in Schwann cells and glia as wcll as neurons. J Histochem Cytochem 38:1301-1311.

Sakata J, Mizuno K, Matsuo H (1986) Tissue distribution and characterization of peptide C-terminal alpha-amidating activity in rat. Biochem Biophys Res Commun 140:230-236.

Savasta M, Palacios JM, Mengod G (1988) Regional localization of the mRNA coding for the neuropeptide cholecystokinin in the rat brain studied by in situ hybridization. Neurosci Lett 93:132-138.

Sawchenko PE, Swanson LW, Grzanna R, Howe PRC, Polak JM, Bloom SR (1985) Colocalization of neuropeptide Y-immunoreactivity in brainstem catecholaminergic neurons that project to the paraventricular nucleus of the hypothalamus. J Comp Neurol 241:138-153.

Shinoda H, Marini AM, Cosi C, Schwartz JP (1989) Brain region and gene specificity of neuropeptide gene expression in cultured astrocytes. Science 245:415-417.

Siegel RE, Young WS III (1985) Detection of preprocholecystokinin and preproenkephalin A mRNAs in rat brain by in situ hybridization histochemistry using complementary RNA probes. Neuropeptides 6 : 573-580.

Stoffers DA, Green CB, Eipper BA (1989) Alternative mRNA splicing generates multiple forms of peptidyl-glycine alpha-amidating monooxygenase in rat atrium. Proc Natl Acad Sci USA 86:735-739.

Stoffers DA, Quafik L'H, Eipper BA (1991) Characterization of novel mRNAs encoding enzymes involved in peptide $\alpha$-amidation. J Biol Chem 266:1701-1707.

Swanson LW (1987) The hypothalamus. In: Integrated systems of the CNS, Pt I, Hypothalamus, hippocampus, amygdala, retina. Handbook of chemical neuroanatomy (Björklund A, Hökfelt T, eds), pp 1-124. Amsterdam: Elsevier.

Swanson LW, Simmons DM (1989) Differential steroid hormone and neural influences on peptide mRNA levels in CRH cells of the paraventricular nucleus: a hybridization histochemical study in the rat. $\mathrm{J}$ Comp Neurol 285:413-435.

Tajima M, Iida T, Yoshida S, Komatsu K, Namba R, Yanagi M, Noguchi M, Okamato $H$ (1990) The reaction product of peptidylglycine $\alpha$-amidating enzyme is a hydroxyl derivative at $\alpha$-carbon of the carboxyl-terminal glycine. J Biol Chem 265:9602-9605.

Takahashi K, Okamoto H, Seino H, Noguchi M (1990) Peptidylglycine alpha-amidating reaction: evidence for a two-step mechanism involving a stable intermediate at neutral $\mathrm{pH}$. Biochem Biophys Res Commun 169:524-530. 
Tatemoto K, Mutt V (1980) Isolation of two novel candidate hormones using a chemical method for finding naturally occurring polypeptides. Nature 285:417-418.

Thiele EA, Marek KL, Eipper BA (1989) Tissue-specific regulation of peptidyl-glycine alpha-amidating monooxygenase expression. Endocrinology 125:2279-2288.

Vale W, Spiess J, Rivier C, Rivier J (1981) Characterization of a 41residue ovine hypothalamic peptide that stimulates secretion of corticotropin and beta-endorphin. Science 213:1394-1397.

Vilijin M-H, Vaysse PJ-J, Zukin RS, Kessler JA (1988) Expression of preproenkephalin mRNA by cultured astrocytes and neurons. Proc Natl Acad Sci USA 58:6551-6555.
Vilijin M-H, Das B, Kessler JA, Fricker LD (1989) Cultured astrocytes and neurons synthesize and secrete carboxypeptidase $E$, a neuopeptide processing enzyme. J Neurochem 53:1487-1493.

Wand GS, Ney RL, Mains RE, Eipper BA (1985) Characterization of peptide alpha-amidation activity in human cerebrospinal fluid and central nervous system tissue. Neuroendocrinology 41:482-489.

Yanagisawa M, Masaki T (1989) Endothelin, a novel endotheliumderived peptide. Pharmacological activities, regulation and possible roles in cardiovascular control. Biochem Pharmacol 38:1877-1883.

Young SD, Tamburini PP (1989) Enzymatic peptidyl $\alpha$-amidation proceeds through formation of an $\alpha$-hydroxylglycine intermediate. $\mathrm{J}$ Am Chem Soc 111:1933-1934. 